\title{
IMPLEMENTASI ENTREPRENEURIAL GOVERNMENT DI KECAMATAN BOGOR TIMUR KOTA BOGOR
}

\section{IMPLEMENTATION OF ENTREPRENEURIAL GOVERNMENT IN BOGOR TIMUR DISTRICT BOGOR CITY}

\author{
Mahmud Danil1* ${ }^{*}$, Akhmad Munjin², G. Goris Seran³ \\ 1,2,3Program Studi Administrasi Publik, Fakultas Ilmu Sosial dan Ilmu Politik, Universitas \\ Djuanda, Jl. Tol Ciawi No. 1, Kotak Pos 35, Bogor 16720 \\ *Korespondensi: Mahmud Danil. Email: mahmud.danil73@gmail.com
}

(Diterima: 21-05-2019; Ditelaah: 05-11-2019; Disetujui: 20-12-2019)

\begin{abstract}
The bureaucracy of district government still often creates the complex and unconducive problems. It fundamentally needs the structural, processual and cultural changes. The bureaucratic changes are taken by the district government in order to improve the efficiency and effectiveness of its work. For this reason, it necessarily applies the strategy to implement the entrepreneurial government. The implementation of the strategy refers to the practices of structural, processual and cultural transformations to reinvent the government bureaucracy. The purpose of this research is to describe the implementation of entrepreneurial government in Bogor Timur District, Bogor City. This research refers to David Osborne and Peter Plastrik's theory which state five dimensions towards entrepreneurial government, namely core strategy, consequence strategy, customer strategy, control strategy and culture strategy. This research uses descriptive method. Data are collected by observation, interview and questionnaire. Data are analyzed by using the formula of Weight Mean Score to get mean score. Results of this analysis partially indicate that the core strategy gets mean score 4.74 perceived as very good. The consequence strategy gets mean score 4.28 perceived as very good. The customer strategy gets mean score 4.33 perceived as very good. The control strategy gets mean score 3.87 perceived as good. The culture strategy gets mean score 4.01 perceived as good. Therefore, result of this analysis of all strategies totally gets mean score 4.25 perceived as very good.
\end{abstract}

Key words: Bogor City, Bureaucracy, Entrepreneurial Government, Public Servive, Reinventing.

\begin{abstract}
ABSTRAK
Birokrasi pemerintahan kecamatan masih sering menimbulkan permasalahan yang kompleks dan kurang kondusif sehingga diperlukan perubahan-perubahan mendasar secara struktural, prosesual dan kultural. Perubahan-perubahan birokrasi tersebut ditempuh pemerintah kecamatan agar dapat meningkatkan efisiensi dan efektivitas kerjanya. Untuk itu perlu diterapkan strategi mewirausahakan birokrasi. Inti menerapkan strategi ini mengacu pada praktek transformasi struktural, prosesual, dan kultural dalam rangka memperbarui dan mewirausahakan sektor pemerintahan. Tujuan penelitian ini adalah untuk mengetahui implementasi entrepreneurial government di Kecamatan Bogor Timur Kota Bogor. Penelitian ini merujuk teori dari David Osborne dan Peter Plastrik yang mengemukakan lima strategi menuju pemerintahan wirausaha, yaitu strategi inti, strategi konsekuensi, strategi pelanggan, strategi pengendalian dan strategi budaya. Penelitian ini menggunakan metode deskriptif. Data dikumpulkan dengan observasi, wawancara dan kuesioner. Analisis data memakai rumus Weight Mean Score untuk menghitung skor rerata. Hasil analisis secara parsial menunjukkan bahwa strategi inti memperoleh skor rerata sebesar 4,74 dengan kategori penilaian sangat baik. Strategi konsekuensi memperoleh skor rerata sebesar 4,28 dengan kategori penilaian sangat baik. Strategi pelanggan memperoleh skor rerata sebesar 4,33 dengan kategori penilaian sangat baik. Strategi pengendalian memperoleh skor rerata sebesar 3,87 dengan kategori penilaian baik. Strategi budaya memperoleh skor rerata sebesar 4,01 dengan kategori penilaian baik. Dengan demikian, hasil analisis secara keseluruhan dimensi strategi memperoleh skor rerata sebesar 4,25 dengan kategori penilaian sangat baik.
\end{abstract}

Kata kunci: Kota Bogor, Birokrasi, Pemerintahan Wirausaha, Pelayanan Publik, Pembaruan.

Danil, Mahmud, Munjin, Akhmad \& Seran, G. Goris. (2020). Implementasi Entrepreneurial Government di Kecamatan Bogor Timur Kota Bogor. Jurnal GOVERNANSI, 6(1): 17-26. 


\section{PENDAHULUAN}

Di era otonomi daerah, pemerintah dalam menyelenggarakan pemerintahan membagi urusan dan mendelegasikan sebagian wewenang kepada pemerintah daerah. Pejabat di daerah harus kreatif, mandiri dan inovatif dalam melaksanakan tugas-tugas kepemerintahan, karena inti dari otonomi daerah ialah keleluasaan dan kebebasan lebih luas untuk mengelola pemerintahan secara mandiri. Pemerintah daerah dapat membangun kemitraan dan bekerja sama langsung dan lebih luas dengan masyarakat dan swasta. Hal inilah yang menjadi cakupan dalam reinventing government yang sering disebut sebagai mewirausahakan birokrasi pemerintahan.

Permasalahan utama yang muncul dalam mewirausahakan birokrasi di pemerintahan daerah pada dasarnya terletak pada instansi pemerintahan itu sendiri. Sejauhmana pelaku birokrasi dapat mengantisipasi perubahan-perubahan yang terjadi baik di lingkungan internal organisasi maupun di masyarakat, seberapa besar usaha pemerintah daerah untuk mentransformasikan semangat wirausaha ke dalam sektor publik dan bagaimana menyikapi perubahan-perubahan yang terjadi merupakan langkah-langkah yang harus diambil secara tepat.

Birokrasi pemerintahan, mulai dari pusat hingga daerah, dan dari kabupaten/ kota, kecamatan, hingga desa/kelurahan, masih memunculkan permasalahan yang kompleks, bahkan menjadi beban bagi publik/masyarakat. Yang terjadi, misalnya, berupa kecenderungan inefisiensi dan inefektivitas pengelolaan keuangan publik sehingga memunculkan perilaku birokrasi yang bersifat cost maximer dan cenderung membebankan biaya kepada masyarakat (Budiarto, et al., 2005).

Hal lain yang juga masih terjadi di dalam birokrasi pemerintahan daerah dewasa ini adalah masih kuatnya perilaku menunggu perintah dari atas, disiplin karena takut aturan (rule driven), inisiatif dan kreativitas kerja yang masih bersifat digerakkan, serta praktek monopoli pelaksanaan urusan yang tidak memungkinkan terjadinya kemitraan pemerintah daerah dan swasta/masyarakat (Budiarto, et al., 2005). Oleh karena itu, karakteristik birokrasi yang tidak kondusif ini tentu saja membutuhkan perubahan-perubahan yang bersifat mendasar.

Kecamatan Bogor Timur merupakan salah satu instansi pemerintahan Kota Bogor yang bertanggung jawab kepada walikota dan membantu walikota dalam penyelenggaraan pemerintahan daerah sesuai dengan kewenangan dan urusannya. Kecamatan Bogor Timur bertugas memberikan pelayanan secara optimal kepada masyarakat, baik pelayanan yang sifatnya public services maupun pelayanan yang sifatnya public goods, berdasarkan kewenangan dan urusan yang didelegasikan.

Birokrasi pemerintahan wirausaha telah diimplementasikan di Kecamatan Bogor Timur Kota Bogor. Berdasarkan hasil observasi yang peneliti lakukan ditemukan masalah yang berkaitan dengan mewirausahakan birokrasi pemerintahan daerah, misalnya pada dimensi strategi budaya. Birokrat daerah belum mampu menerapkan sikap kebersamaan baik kepada pegawai ataupun kepada masyarakat dengan mengembangkan kebiasaan dan nilai baru, memberi pengalaman kepada jenis pekerjaan, dan interaksi yang kondusif dengan masyarakat/swasta. Hal ini tentu saja mempengaruhi penyediaan dan efektivitas pelayanan kepada masyarakat. Pada tahun 2018, Kecamatan Bogor Timur memperoleh indeks kepuasan masyarakat dengan nilai rerata 77,22 yang dikategorikan baik. Dalam konteks ini, hal-hal mana yang sudah baik tetap dipertahankan dan hal-hal mana yang masih belum kondusif perlu diperbaiki dan ditingkatkan. Dengan menerapkan, pemerintahan wirausaha, masalah-masalah tersebut menjadi tugas pemerintah daerah untuk menyediakan pelayanan yang berkualitas dan meningkatkan kepuasan masyarakat. 
Berdasarkan latar belakang tersebut, maka penelitian ini berusaha mengkaji implementasi entrepreneurial government di Kecamatan Bogor Timur Kota Bogor. Fokus kajian mengarah pada lima dimensi strategi entrepreneurial government, yakni strategi inti, strategi konsekuensi, strategi pelanggan, strategi pengendalian dan strategi budaya. Permasalahan yang hendak dijawab dalam penelitian ini adalah bagaimana implementasi entrepreneurial government di Kecamatan Bogor Timur Kota Bogor, apa hambatan dalam mengimplementasikan entrepreneurial government di Kecamatan Bogor Timur Kota Bogor, dan apa upaya yang dapat dilakukan dalam mengimplementasikan entrepreneurial government di Kecamatan Bogor Timur Kota Bogor.

\section{MATERI DAN METODE}

\section{Konsep/Teori yang Relevan}

Osborne dan Gaebler (1996), Osborne dan Plastrik (2000) mendefinisikan mewirausahakan (entrepreneurial) lebih dari sekedar persoalan ekonomi, yaitu terutama berkenaan dengan "semangat dan usaha mempergunakan sumber daya dengan cara baru untuk memaksimalkan produktivitas dan efektivitas". Definisi mewirausahakan ini juga dapat dipakai untuk menjelaskan birokrasi sebagai sektor publik/pemerintahan, sehingga kemudian muncul konsep "pemerintahan wirausaha/entrepreneurial government" (Budiarto, et al., 2005).

Osborne dan Plastrik (2000) berpendapat bahwa strategi mewirausahakan birokrasi pemerintahan pada intinya tertuju pada "pembaruan (reinventing) menyangkut restrukturisasi organisasi dan sistem pemerintahan dengan mengubah unsur pendongkrak utama berupa tujuan, insentif, akuntabilitas, distribusi kekuasaan, dan budayanya" (Budiarto, et al., 2005).

Osborne dan Plastrik (2000) menekankan bahwa strategi mewirausahakan birokrasi pemerintahan pada hakekatnya berhubungan dengan "transformasi sistem dan organisasi pemerintah secara fundamental guna menciptakan peningkatan dramastis dalam efektivitas, efisiensi, dan kemampuan untuk melakukan inovasi; dimana transformasi ini dicapai dengan mengubah tujuan, sistem insentif, pertanggungjawaban, struktur kekuasaan, dan budaya sistem dan organisasi pemerintah" (Budiarto, et al., 2005).

Selanjutnya Osborne dan Plastrik (2000) mengemukakan lima strategi untuk menjalankan pemerintahan wirausaha (Budiarto, et al., 2005) sebagai berikut:

Pertama: Strategi Inti (Core Strategy). Strategi inti berhubungan dengan strategi yang menjelaskan tentang tujuan. Tujuan menjadi pendongkrak utama karena berkaitan dengan fungsi inti pemerintahan, yaitu fungsi mengarahkan (steering). Strategi inti diukur berdasarkan tiga indikator, yaitu kejelasan tujuan, kejelasan peran dan kejelasan arah.

Kedua: Strategi Konsekuensi (Consequence Strategy). Strategi konsekuensi menentukan sistem insentif pemerintah yang mengubah insentif menjadi konsekuensi atas kinerja yang dihasilkan. Pendongkrak utama ada pada insentif. Strategi konsekuensi diukur berdasarkan tiga indikator, yaitu persaingan terkendali, manajemen usaha dan manajemen kinerja.

Ketiga: Strategi Pelanggan (Customer Strategy). Strategi pelanggan memusat pada akuntabilitas, yaitu kepada siapa seharusnya pemerintah bertanggung jawab. Yang menjadi pendongkrak utama adalah akuntabilitas, dimana pemerintah bertanggung jawab kepada masyarakat (public) sebagai pelanggan pelayanan publik (customer). Strategi pelanggan diukur berdasarkan tiga indikator, yaitu pilihan pelanggan, pilihan kompetitif dan pemastian mutu layanan.

Keempat: Strategi Pengendalian (Control Strategy). Strategi pengendalian menentukan letak kekuasaan pengambilan keputusan. Kekuasaan menjadi pendongkrak utama, dimana pengambilan keputusan 
bergeser dari yang sifatnya hirarkis menjadi misi bersama. Strategi pengendalian diukur berdasarkan tiga indikator, yaitu pemberdayaan organisasi, pemberdayaan pegawai dan pemberdayaan masyarakat.

Kelima: Strategi Budaya (Culture Strategy). Strategi budaya menjadi bagian kritikal dari sistem yang menentukan nilai, norma, sikap dan harapan pemerintah. Budaya ditentukan oleh unsur-unsur pendongkrak lain, yaitu tujuan, insentif, akuntabilitas, dan kekuasaan. Mengubah unsur-unsur pendongkrak tersebut berarti budaya ikut berubah. Yang menjadi pendongkrak utama adalah budaya. Strategi budaya diukur berdasarkan tiga indikator, yaitu membangun perasaan bersama, mengubah kebiasaan dan mengubah pikiran.

\section{Metode}

Penelitian ini menggunakan pendekatan kuantitatif untuk menjelaskan data tentang implementasi entrepreneurial government di Kecamatan Bogor Timur Kota Bogor. Data yang diperoleh melalui angket/kuesioner berbentuk data ordinal. Data angket/kuesioner kemudian dikuantifikasikan dengan menghitung rerata skor (mean score) untuk menilai tingkat implementasi entreprenerial government.

Metode yang digunakan dalam penelitian ini adalah metode penelitian yang bersifat deskriptif. Sugiyono (2003) mendefinisikan metode penelitian yang bersifat deskriptif sebagai "suatu penelitian dengan cara melakukan pengamatan secara langsung terhadap masalah-masalah yang sedang berlangsung dan menggambarkan keadaan sebenarnya, kemudian dianalisis untuk ditarik kesimpulan". Populasi penelitian ini adalah seluruh pegawai Kecamatan Bogor Timur Kota Bogor. Dari populasi tersebut, peneliti menarik sampel dengan menggunakan sampling jenuh. Menurut Sugiyono (2003), sampling jenuh adalah teknik penentuan sampel bila semua anggota populasi digunakan sebagai sampel.
Untuk memperoleh data yang diperlukan, peneliti menggunakan beberapa teknik pengumpulan data sebagai berikut:

1) Penelitian kepustakaan (library research), yaitu penelitian yang berusaha untuk menelusuri kepustakaan terkait dalam rangka mendapatkan informasi dan data dengan cara membaca, mempelajari, dan memahami buku-buku dan bahan-bahan pustaka, dokumen dan peraturan perundang-undangan terkait guna melengkapi analisis penelitian tentang implementasi entrepreneurial government.

2) Penelitian lapangan (field research), yaitu penelitian yang ditempuh untuk mengumpulkan dan mendapatkan data dan informasi secara langsung dari lapangan penelitian tentang implementasi entrepreneurial government.

Untuk kepentingan penelitian lapangan (field research), peneliti mempergunakan tiga teknik pengumpulan data, yaitu:

1) Pengamatan (observation), yaitu suatu cara penelitian yang ditempuh untuk mengumpulkan dan memperoleh data dan informasi dari lapangan dengan mengamati secara langsung obyek yang diteliti. Yang diamati dalam penelitian ini adalah mengenai entrepreneurial government.

2) Wawancara (interview), yaitu cara penelitian untuk mengumpulkan data dan informasi melalui cara melakukan tanya-jawab dengan responden/informan mengenai hal-hal yang mengacu pada obyek penelitian. Yang diwawancarai melalui penelitian ini adalah tentang implementasi entrepreneurial government.

3) Angket (questionnaires), yaitu suatu cara penelitian untuk mengumpulkan dan mendapatkan data dan informasi dengan memberikan daftar pertanyaan tertulis yang telah ditentukan isi dan materinya kepada responden/informan penelitian. Pertanyaan yang diajukan bersifat tertutup, yaitu pertanyaan 
tertulis yang diajukan disertai dengan alternatif jawaban, dan responden/ informan diminta untuk memilih salah satu jawaban yang telah disediakan. Angket/kuesioner disusun menggunakan skala Likert (Sugiono, 2003) berbentuk ordinal, yang menyediakan lima alternatif jawaban, mulai dari sangat baik, baik, cukup, tidak baik, dan sangat tidak baik.

Analisis data penelitian, berdasarkan pemikiran Labovits, et al. (1982), menggunakan perhitungan Weight Mean Score (Siregar, 1982) yang bertujuan untuk menghitung skor rerata (mean score). Skor rerata dihitung berdasarkan jawaban responden terhadap angket/kuesioner, dimana jawaban sangat baik diberikan skor 5, baik dengan skor 4, cukup dengan skor 3, tidak baik dengan skor 2, dan sangat tidak baik dengan skor 1 . Hasil perhitungan skor rerata menjadi dasar penafsiran termasuk kategori sangat baik, baik, cukup, tidak baik, atau sangat tidak baik dalam implementasi entrepreneurial government di Kecamatan Bogor Timur Kota Bogor.

\section{HASIL DAN PEMBAHASAN}

Rekapitulasi jawaban responden tentang implementasi entrepreneurial government di Kecamatan Bogor Timur Kota Bogor menggunakan lima strategi sebagai dimensi-dimensi penelitian implementasi pemerintahan wirausaha sebagaimana dikemukakan oleh Osborne dan Plastrik (2000).

Adapun lima dimensi strategi dalam penelitian tentang implementasi entrepreneurial government di Kecamatan Bogor Timur Kota Bogor, yaitu strategi inti (core strategy), strategi konsekuensi (consequence strategy), strategi pelanggan (customer strategy), strategi pengendalian (control strategy), dan strategi budaya (culture strategy). Hasil dan pembahasan terhadap masing dimensi strategi implementasi pemerintahan wirausaha (entrepreneurial government) digambarkan sebagai berikut:
Tabel 1. Rekapitulasi Dimensi Strategi Inti

\begin{tabular}{lcc}
\hline Indikator & Rerata & Kategori \\
\hline $\begin{array}{l}\text { Kejelasan } \\
\text { Tujuan }\end{array}$ & 4,90 & Sangat Baik \\
\hline Kejelasan Peran & 4,81 & Sangat Baik \\
\hline Kejelasan Arah & 4,52 & Sangat Baik \\
\hline Jumlah & 4,74 & Sangat Baik \\
\hline
\end{tabular}

Sumber: Hasil Penelitian, 2019

Rekapitulasi pembahasan strategi inti entrepreneurial government di Kecamatan Bogor Timur Kota Bogor menunjukkan skor rerata sebesar 4,74 dengan kategori penilaian sangat baik. Hal ini juga dibuktikan berdasarkan hasil wawancara dengan camat dan pegawai Kecamatan Bogor Timur Kota Bogor yang menyatakan bahwa tujuan, peran dan arah organisasi Kecamatan Bogor Timur Kota Bogor berjalan dengan sangat baik karena memiliki pedoman rencana strategis sehingga pegawai dapat menjalankan tugas dan fungsinya sesuai dengan pedoman yang telah ditetapkan dan perjanjian kinerja yang telah disepakati pada tahun berjalan.

Tabel 2. Rekapitulasi Dimensi Strategi Konsekuensi

\begin{tabular}{lcc}
\hline Indikator & Rerata & Kategori \\
\hline $\begin{array}{l}\text { Persaingan } \\
\text { Terkendali }\end{array}$ & 4,62 & Sangat Baik \\
\hline $\begin{array}{l}\text { Manajemen } \\
\text { Usaha }\end{array}$ & 3,90 & Baik \\
\hline $\begin{array}{l}\text { Manajemen } \\
\text { Kinerja }\end{array}$ & 4,33 & Sangat Baik \\
\hline Jumlah & 4,28 & Sangat Baik \\
\hline
\end{tabular}

Sumber: Hasil Penelitian, 2019

Rekapitulasi pembahasan strategi konsekuensi entrepreneurial government di Kecamatan Bogor Timur Kota Bogor menunjukkan skor rerata sebesar 4,28 dengan kategori penilaian sangat baik. Strategi konsekuensi berkaitan dengan sistem insentif pemerintah yang mengubah insentif menjadi kinerja yang dihasilkan. Perjanjian kinerja yang telah disepakati antara camat dengan pegawai Kecamatan Bogor Timur Kota Bogor mendasari penyelenggaraan tugas dan fungsi pegawai. Hasil wawancara menggambarkan pencapaian kinerja yang sangat baik. 
Tabel 3. Rekapitulasi Dimensi Strategi Pelanggan

\begin{tabular}{lcc}
\hline Indikator & Rerata & Kategori \\
\hline $\begin{array}{l}\text { Pilihan } \\
\text { Pelanggan }\end{array}$ & 4,57 & Sangat Baik \\
\hline $\begin{array}{l}\text { Pilihan } \\
\text { Kompetitif }\end{array}$ & 4,24 & Sangat Baik \\
\hline $\begin{array}{l}\text { Pemastian Mutu } \\
\text { Layanan }\end{array}$ & 4,19 & Baik \\
\hline Jumlah & 4,33 & Sangat Baik \\
\hline
\end{tabular}

Sumber: Hasil Penelitian, 2019

Rekapitulasi pembahasan strategi pelanggan entrepreneurial government di Kecamatan Bogor Timur Kota Bogor menunjukkan skor rerata sebesar 4,33 dengan kategori penilaian sangat baik. Strategi pelanggan memusat pada akuntabilitas, yaitu kepada siapa seharusnya pemerintah bertanggung jawab. Yang menjadi pendongkrak utama adalah akuntabilitas, dimana pemerintah bertanggung jawab kepada masyarakat (public) sebagai pelanggan pelayanan publik (customer). Kendati dimensi strategi pelanggan dinilai sangat baik, akan tetapi faktor loyalitas kepada atasan yang mengangkatnya menjadi lebih utama. Pada hal, strategi pelanggan untuk mengimplementasikan entrepreneurial government terutama menekankan bagaimana birokrasi pemerintahan kecamatan berorientasi kepada masyarakat yang dilayani sebagai pelanggan pelayanan publik.

Tabel 4. Rekapitulasi Dimensi Strategi Pengendalian

\begin{tabular}{lcc}
\hline Indikator & Rerata & Kategori \\
\hline $\begin{array}{l}\text { Pemberdayaan } \\
\text { Organisasi }\end{array}$ & 3,67 & Baik \\
\hline $\begin{array}{l}\text { Pemberdayaan } \\
\text { Pegawai }\end{array}$ & 4,05 & Baik \\
\hline $\begin{array}{l}\text { Pemberdayaan } \\
\text { Masyarakat }\end{array}$ & 3,90 & Baik \\
\hline Jumlah & 3,87 & Baik \\
\hline
\end{tabular}

Sumber: Hasil Penelitian, 2019

Rekapitulasi pembahasan strategi pengendalian entrepreneurial government di Kecamatan Bogor Timur Kota Bogor menunjukkan skor rerata sebesar 3,87 dengan kategori penilaian baik. Strategi pengendalian menentukan letak kekuasaan pengambilan keputusan. Kekuasaan men- jadi pendongkrak utama, dimana pengambilan keputusan bergeser dari yang sifatnya hirarkis menjadi misi bersama. Kendati dimensi strategi pengendalian dinilai baik, akan tetapi skor nilai yang diperoleh paling rendah di antara dimensidimensi strategi lainnya. Hal ini terkait dengan faktor yang mempengaruhi, yaitu persoalan kompetensi pegawai dalam memangku jabatan sebagai bagian dari pemberdayaan organisasi dan pegawai.

Kompetensi pegawai dalam memegang jabatan sangat substansial bagi pemberdayaan organisasi kecamatan, akan tetapi sistem perkoncoan menghambat pemberdayaan pegawai dan organisasi. Faktor kompetensi, pengetahuan dan kemampuan pegawai sudah kurang diperhatikan dalam memangku jabatan. Kompetensi diperlukan dalam prasyarat pemenuhan jabatan. Hal ini mempengaruhi inovasi dan kreativitas aparatur daripada sekedar loyal dan taat pada aturan yang kaku. Hal demikian dimungkinkan karena dalam birokrasi pemerintahan terdapat praktek kewenangan diskresi seluasluasnya. Kebanyakan pegawai tidak berani untuk mengadakan inovasi atau bentuk kreativita guna pemberdayaan organisasi dan pegawai karena hal tersebut dianggap melanggar aturan.

Tabel 5. Rekapitulasi Dimensi Strategi Budaya

\begin{tabular}{lcc}
\hline Indikator & Rerata & Kategori \\
\hline $\begin{array}{l}\text { Membangun } \\
\begin{array}{l}\text { Perasaan } \\
\text { Bersama }\end{array}\end{array}$ & 4,28 & Sangat Baik \\
\hline $\begin{array}{l}\text { Mengubah } \\
\text { Kebiasaan }\end{array}$ & 3,76 & Baik \\
\hline $\begin{array}{l}\text { Mengubah } \\
\text { Pikiran }\end{array}$ & 4,00 & Baik \\
\hline Jumlah & 4,01 & Baik \\
\hline Sumber: Hasil Penelitian, 2019 &
\end{tabular}

Rekapitulasi pembahasan strategi budaya entrepreneurial government di Kecamatan Bogor Timur Kota Bogor menunjukkan skor rerata sebesar 4,01 dengan kategori penilaian baik. Strategi budaya menjadi bagian kritikal dari sistem yang 
menentukan nilai, norma, sikap dan harapan pemerintah. Budaya ditentukan oleh unsur-unsur pendongkrak lain, yaitu tujuan, insentif, akuntabilitas, dan kekuasaan. Mengubah unsur-unsur pendongkrak tersebut berarti budaya ikut berubah.

Kendati dimensi strategi budaya dinilai baik, akan tetapi aspek pengetahuan dan sikap aparatur birokrasi pemerintahan kecamatan termasuk faktor yang ikut mempengaruhi implementasi entrepreneurial government di Kecamatan Bogor Timur Kota Bogor, dimana konsep entrepreneurial government masih belum sepenuhnya dipahami oleh aparatur pemerintahan kecamatan. Aspek pengetahuan dan sikap aparatur pemerintahan kecamatan terhadap entrepreneurial government, dimana konsep entrepreneurial government berasal dari Barat sehingga penyesuaian konteks pemerintahan wirausaha masih belum sepenuhnya dipahami oleh aparatur pemerintahan kecamatan.

Berdasarkan pembahasan tersebut, maka rekapitulasi keseluruhan strategi implementasi entrepreneurial government di Kecamatan Bogor Timur Kota Bogor adalah sebagai berikut:

Tabel 6. Rekapitulasi Implementasi Entrepreneurial Government

\begin{tabular}{lcc}
\hline Indikator & Rerata & Kategori \\
\hline Strategi Inti & 4,74 & Sangat Baik \\
\hline $\begin{array}{l}\text { Strategi } \\
\text { Konsekuensi }\end{array}$ & 4,28 & Sangat Baik \\
\hline $\begin{array}{l}\text { Strategi } \\
\text { Pelanggan }\end{array}$ & 4,33 & Sangat Baik \\
\hline $\begin{array}{l}\text { Strategi } \\
\text { Pengendalian }\end{array}$ & 3,87 & Baik \\
\hline Strategi Budaya & 4,01 & Baik \\
\hline Jumlah & 4,25 & Sangat Baik \\
\hline
\end{tabular}

Sumber: Hasil Penelitian, 2019

Dengan demikian, implementasi entrepreneurial government di kecamatan Bogor Timur Kota Bogor menunjukkan skor rerata 4,25 yang diinterpretasi berada pada kategori sangat baik. Hal ini menunjukkan bahwa Kecamatan Bogor Timur Kota Bogor telah menerapkan pemerintahan wirausaha untuk dapat bersaing dengan organisasi pemerintahan lain dalam segi pelayanan kepada masyarakat.

Penelitian mengenai implementasi entrepreneurial government di Kecamatan Bogor Timur Kota Bogor yang ditinjau dari strategi inti, strategi konsekuensi, strategi pelanggan, strategi pengendalian, dan strategi budaya menemukan hambatanhambatan sebagai berikut:

1) Hambatan rendahnya indikator tingkat manajemen usaha organisasi pada dimensi strategi konsekuensi dalam implementasi entrepreneurial government di Kecamatan Bogor Timur Kota Bogor. Indikator manajemen usaha organisasi dalam dimensi strategi konsekuensi memperoleh skor rerata sebesar 3,90 dengan kategori penilaian baik. Hal ini menunjukkan bahwa manajemen usaha di Kecamatan Bogor Timur Kota Bogor dalam memperkuat insentif masih memiliki banyak hambatan. Karena manajemen usaha tidak bisa diterapkan untuk semua jenis organisasi pemerintah, maka hasil finansial bukanlah indikator yang tepat untuk mengukur keberhasilan karena aktivitas organisasi bukanlah aktivitas yang bebannya harus ditanggung oleh pelanggan secara langsung.

2) Hambatan rendahnya indikator tingkat pemberdayaan organisasi, pegawai dan masyarakat pada dimensi strategi pengendalian dalam implementasi entrepreneurial government di Kecamatan Bogor Timur Kota Bogor. Kendati dimensi strategi pengendalian memperoleh skor rerata sebesar 3,87 dengan kategori penilaian baik, akan tetapi skor nilai tersebut termasuk paling rendah apabila dibandingkan dengan dimensi strategi lainnya. Hal ini menunjukkan bahwa strategi pengendalian dalam birokrasi pemerintahan kecamatan masih perlu ditingkatkan, karena pemberdayaan organisasi harus dilakukan dengan baik sebagai salah satu alat kontrol. Di samping itu, pember- 
dayaan pegawai juga harus ditingkatkan agar dapat berkontribusi dalam memberikan keputusan untuk masa depan pemerintahan. Demikian juga, pemberdayaan masyarakat perlu ditingkatkan dalam mewujudkan visi kecamatan.

3) Hambatan dalam implementasi entrepreneurial government di Kecamatan Bogor Timur Kota Bogor juga bersumber dari faktor budaya organisasi, yaitu berkaitan dengan persoalan mentalitas dan perilaku kerja, walaupun hasil penelitian menunjukkan bahwa strategi budaya memperoleh skor rerata sebesar 4,01 dengan kategori penilaian baik.

Beberapa upaya perbaikan yang dapat dilakukan untuk mengatasi hambatan dalam implementasi entrepreneurial government di Kecamatan Bogor Timur Kota Bogor adalah sebagai berikut:

1) Hambatan rendahnya tingkat manajemen usaha organisasi pada dimensi strategi konsekuensi dalam implementasi entrepreneurial government di Kecamatan Bogor Timur Kota Bogor, diupayakan agar pemerintah daerah dapat memaksa organisasi untuk memberi pelayanan terbaik sebagaimana perusahaan bisnis dengan laba sebagai tujuan akhirnya. Hal ini tidak berarti mendorong aparatur birokrasi untuk melakukan pemungutan liar dalam pelayanan. Usaha yang bisa dilakukan adalah dengan mendirikan badan usaha untuk memperoleh anggaran tanpa harus mengandalkan pajak dari masyarakat. Usaha lain yang dapat dilakukan pada indikator manajemen usaha adalah bekerja sama/bermitra dengan pihak swasta untuk memperoleh anggaran dalam proses pembangunan daerah.

2) Hambatan rendahnya tingkat pemberdayaan pegawai pada dimensi strategi pengendalian dalam implementasi entrepreneurial government di Kecamatan Bogor Timur Kota Bogor, diupayakan agar pemerintah daerah dapat memberdayakan pegawai sehingga dapat berkontribusi secara signifikan dengan berani mengambil keputusan, menanggapi pelanggan dengan baik dan dapat memberikan upaya peningkatan pemberdayaan masyarakat.

3) Hambatan rendahnya budaya organisasi pada dimensi strategi budaya dalam implementasi entrepreneurial government di Kecamatan Bogor Timur Kota Bogor, diupayakan agar pemerintah daerah mengarahkan kembali tujuan organisasi, sistem insentif, akuntabilitas/pertanggungjawaban dan distribusi kekuasaan, maka budaya organisasi ikut berubah. Sehingga budaya organisasi dapat terbentuk dan dapat membangun misi bersama mengenai masa depan organisasi.

\section{KESIMPULAN DAN IMPLIKASI}

\section{Kesimpulan}

Berdasarkan pembahasan tentang implementasi entrepreneurial government di Kecamatan Bogor Timur Kota Bogor, maka peneliti menyimpulkan hal-hal sebagai berikut:

1) Implementasi entrepreneurial government di Kecamatan Bogor Timur Kota Bogor yang ditinjau berdasarkan keseluruhan dimensi strategi, yaitu strategi inti, strategi konsekuensi, strategi pelanggan, strategi pengendalian dan strategi budaya, memperoleh skor rerata sebesar 4,25 dengan kategori penilaian sangat baik.

2) Implementasi entrepreneurial government di Kecamatan Bogor Timur Kota Bogor yang diteliti berdasarkan masingmasing dimensi strategi memperoleh hasil sebagai berikut: (a) Strategi inti memperoleh skor rerata sebesar 4,74 dengan kategori penilaian sangat baik. (b) Strategi konsekuensi memperoleh skor rerata sebesar 4,28 dengan kategori penilaian sangat baik. (c) Strategi pelanggan memperoleh skor rerata sebesar 4,33 dengan kategori penilaian 
sangat baik. (d) Strategi pengendalian memperoleh skor rerata sebesar 3,87 dengan kategori penilaian baik. (e) Strategi budaya memperoleh skor rerata sebesar 4,01 dengan kategori penilaian baik.

3) Hambatan dalam implementasi entrepreneurial government di Kecamatan Bogor Timur Kota Bogor bersumber dari setidaknya tiga hal, yaitu: (a) rendahnya tingkat manajemen usaha organisasi dalam strategi konsekuensi, (b) rendahnya tingkat pemberdayaan organisasi, pegawai dan masyarakat dalam dimensi strategi pengendalian, dan (c) persoalan mentalitas dan perilaku kerja dalam dimensi strategi budaya. Terdapat setidaknya tiga upaya yang dapat dilakukan untuk mengatasi hambatan dalam implementasi entrepreneurial government di Kecamatan Bogor Timur Kota Bogor, yaitu: (a) menyediakan pelayanan terbaik dan membangun kemitraan dengan swasta dan masyarakat, (b) memberdayakan pegawai dalam mengambil keputusan, menanggapi pelanggan dengan baik dan memberikan upaya peningkatan pemberdayaan masyarakat, (c) melakukan perubahan terhadap budaya organisasi dengan mendorong perubahan dalam hal tujuan organisasi, sistem insentif, akuntabilitas/pertanggungjawaban dan distribusi kekuasaan.

\section{Implikasi}

Implikasi teoritis yang mengemuka dari penelitian ini adalah pembuktian terhadap teori pemerintahan wirausaha (entrepreneurial government) disertai dengan pengaplikasian empiris terhadap konsep-konsep strategi inti (core strategy), strategi konsekuensi (consequence strategy), strategi pelanggan (customer strategy), strategi pengendalian (control strategy), dan strategi budaya (culture strategy).

Implikasi praktis dari penelitian ini diharapkan dapat bermanfaat sebagai bahan masukan, pertimbangan dan sumbangan pemikiran yang bermanfaat dalam mengimplementasikan entrepreneurial government, mewirausahakan birokrasi pemerintahan di Kecamatan Bogor Timur Kota Bogor.

\section{DAFTAR PUSTAKA}

\section{Buku}

Budiarto, Diani; Krisna, Eri \& Seran, G. Goris. (2005). Perspektif Pemerintahan Daerah: Otonomi, Birokrasi, dan Pelayanan Publik. Bogor: FISIP Universitas Djuanda.

Faisal, Sanapiah. (1999). Format-format Penelitian Sosial. Cetakan Keempat, Jakarta: PT RajaGrafindo Persada.

Labovits, Sanford, et al. (1982). Metode Riset Sosial: Suatu Pengantar. Terjemahan Bakrie Siregar. Jakarta: Erlangga.

Mustafa, Delly. (2014). Birokrasi Pemerintahan. Bandung: Alfabeta.

Osborne, David \& Gaebler, Ted. (1996). Mewirausahakan Birokrasi, Mentransformasi Semangat Wirausaha ke dalam Sektor Publik. Jakarta: Pustaka Binaman Pressindo.

Osborne, David \& Plastrik, Peter. (2000). Memangkas Birokrasi, Lima Strategi Menuju Pemerintahan Wirausaha. Jakarta: PPM.

Sugiyono. (2003). Metode Penelitian Administrasi Negara. Bandung: Alfabeta.

Supranto, J. (1996). Statistik Teori dan Aplikasi. Jakarta: Erlangga.

Widjaja, HAW. (2002). Otonomi Daerah dan Daerah Otonom. Jakarta: Rajawali Pers.

\section{Proseding/Skripsi}

Danil, Mahmud; Olisah; Resmala, Vilia; Ruyani, Arifin Ima \& Seran, G. Goris. (2018). "Application of Good Governance Principles in Babakan Madang, Bogor". Dalam: Proceedings Capacity Empowerment Based on Local Resources for Human Well Being: Uniqueness, 
Selling Point, Value Creation, The Second BICSS 2018, Bogor: Unida Press.

Fauzan, Fahri. (2013). Kualitas Pelayanan Publik Di Kecamatan Bogor Timur Kota Bogor. Skripsi. Bogor: Program Studi Adminsitrasi Negara Fakultas Ilmu Sosial dan Ilmu Politik Universitas Djuanda.

\section{Peraturan Perundang-undangan}

Undang-Undang Nomor 23 Tahun 2014 tentang Pemerintahan Daerah (Lembaran Negara Republik Indonesia Tahun 2014 Nomor 244, Tambahan Lembaran Negara Republik Indonesia Nomor 5587). 